Tropical Journal of Pharmaceutical Research March 2020; 19 (3): 583-586

ISSN: $1596-5996$ (print); 1596-9827 (electronic)

(C) Pharmacotherapy Group, Faculty of Pharmacy, University of Benin, Benin City, 300001 Nigeria.

Available online at http://www.tjpr.org

Original Research Article

http://dx.doi.org/10.4314/tjpr.v19i3.18

\title{
Cytotoxic effect of acetogenins and sesquiterpenes obtained from the Red alga Laurencia majuscula
}

\author{
Hajer S Alorfi ${ }^{1 *}$, Mohamed A Ghandourah², Adnan J Turki² \\ ${ }^{1}$ Department of Chemistry, Faculty of Science, King Abdulaziz University, PO Box 80203, ${ }^{2}$ Department of Marine Chemistry, \\ Faculty of Marine Sciences, King Abdulaziz University, PO Box 80207, Jeddah 21589, Saudi Arabia \\ *For correspondence: Email: halorfi@kau.edu.sa
}

Sent for review: 15 October 2019

Revised accepted: 26 February 2020

\begin{abstract}
Purpose: To evaluate the cytotoxicity of $n$-hexane extract and its metabolites obtained from the red alga, Laurencia majuscula, against three cancer cell lines HCT-116 (colon cancer), PC-3 (prostate cancer) and HepG2 (liver cancer) cells; and to identify the phytochemical compound(s) involved.

Methods: Solvent extraction, thin layer chromatography, aluminum oxide column chromatography, and preparative thin layer chromatography (PTLC) were employed for isolating pure compounds from $n$ hexane extract of Laurencia majuscula. Nuclear magnetic resonance (NMR) and mass spectrometry (MS) measurements were used for structural elucidation of the compounds. The cytotoxicity of the nonpolar extract and isolated compounds were evaluated against HCT, PC-3, and HepG2 cells using MTT assay, relative to the standard cytotoxic drug (cisplatin).

Results: Three sesquiterpenes (1, 2 and 8), and five acetogenins (3-7) were isolated from the $n$-hexane extract. The $n$-hexane extract showed higher potent cytotoxic effect than sesquiterpenes and the acetogenins (3-7).

Conclusion: These results indicate that the $n$-hexane extract of Laurencia majuscula exerts significant cytotoxicity against HCT-116, PC-3 and HepG2 cell lines, thus suggesting that the plant extract may be effective chemotherapeutic agents for the management of colon, postrate and liver cancer.
\end{abstract}

Keywords: Red Sea alga, Rhodomelaceae, Polyketides, Terpenes, Anticancer

\begin{abstract}
This is an Open Access article that uses a fund-ing model which does not charge readers or their institutions for access and distributed under the terms of the Creative Commons Attribution License (http://creativecommons.org/licenses/by/4.0) and the Budapest Open Access Initiative (http://www.budapestopenaccessinitiative.org/read), which permit unrestricted use, distribution, and reproduction in any medium, provided the original work is properly credited.

Tropical Journal of Pharmaceutical Research is indexed by Science Citation Index (SciSearch), Scopus, International Pharmaceutical Abstract, Chemical Abstracts, Embase, Index Copernicus, EBSCO, African Index Medicus, JournalSeek, Journal Citation Reports/Science Edition, Directory of Open Access Journals (DOAJ), African Journal Online, Bioline International, Open-J-Gate and Pharmacy Abstracts
\end{abstract}

\section{INTRODUCTION}

Marine red algae comprise of diverse bioactive compounds that exert antimicrobial, antiinflammatory, cytotoxic, antifoulants, insecticidal and immunosuppressive effects $[1,2]$. It has been reported that the genus Laurencia is the most productive in the Rhodomelaceae genera. Sesquiterpenoids, diterpenoids, and cyclic and polycyclic haloethers $\left(\mathrm{C}_{15}\right.$ acetogenins $)$ are polyketides. Steroids are frequently isolated from Laurencia species [1-3]. The diversity of halogenated metabolites makes them play vital roles as chemotaxonomic markers [4-6]. However, not much is known about the bioactive constituents of Laurencia majuscula specifically responsible for its activity. Thus, the present study was carried out to investigate the cytotoxicity of $n$-hexane extract of Laurencia majuscula, and to isolate and identify the 
cytotoxic compounds in their pure forms.

\section{EXPERIMENTAL}

\section{Materials}

Laurencia majuscula Lamouroux was collected in September, 2018 from Al-rays area, Saudi Arabia (23 $34^{\circ} 11.3^{\prime \prime} \mathrm{N}$; 38 $\left.38^{\circ} 36^{\prime} 10.6^{\prime \prime} \mathrm{E}\right)$. A voucher sample (JAD 0366) was deposited at Faculty of Marine Science, King Abdulaziz University.

\section{Cell lines and reagents}

The three cell lines HCT-116 (colon cancer), PC3 (prostate cancer), and HepG2 (liver cancer) were purchased from American Type Culture Collection. All cells were cultured in DMEM (12604F, Lonza Verviers SPRL, Belgium) supplemented with $5 \%$ fetal bovine serum (S001B-BR, Life Science Group L, UK); $100 \mathrm{IU} / \mathrm{mL}$ penicillin and $100 \mu \mathrm{g} / \mathrm{mL}$ streptomycin (17-602E, Lonza Verviers SPRL, Belgium. The rest of assay was performed as previously reported $[7,8]$.

\section{Extraction and isolation}

Laurencia majuscula (260 g) was dried, and extracted with $n$-hexane. The $n$-hexane extract $(4.2 \mathrm{~g})$ was fractionated on a neutral aluminum oxide column, employing gradient elution ( $n$ hexane: diethyl ether), and 50-ml fractions were collected. The fractions were combined into four pools (A, B, C and D). Pool A, which was eluted with $n$-hexane: diethyl ether (98:2, v:v), was purified on a neutral aluminum oxide column, and it yielded a fraction containing compounds 1 and 2. Compounds 1 and 2 were purified using Si-Gel PTLC and eluted with $n$-hexane. Pool $\mathrm{B}$, which was eluted with $n$-hexane: ether (95:5, v:v) was purified on Si-Gel PTLC and eluted with $n$ hexane/diethyl ether mixture to yield compounds 3-5. Fraction $C$, which was eluted with $n$-hexane: ether (85:15, v:v) was purified on Si-Gel PTL and eluted with $n$-hexane/diethyl ether $(85: 15, \mathrm{v}: \mathrm{v})$ to yield compounds 6 and 7. Pool D, which was eluted with $n$-hexane: diethyl ether (80:20, v:v) was purified on Si-Gel PTL. Elution was done with $n$-hexane: diethyl ether (75:25 v:v) to yield compound 8.

\section{Cytotoxicity assay}

The cancer cells were seeded in 96-well plates at a density of 5000 cells/well and incubated for 24 $\mathrm{h}$ at $37^{\circ} \mathrm{C}$ in an incubator containing $5 \% \mathrm{CO}_{2}$. Thereafter, the cells were treated with serial dilution of the Conus extract $(50,25,12.5,6.25$,
3.125, and $1.56 \mu \mathrm{g} / \mathrm{mL}$ ) and after $48 \mathrm{~h}$, the viability of each cancer cell line was determined using 3-(4,5-dimethylthiazol-2-yl)-2,5-diphenyl tetrazolium bromide (MTT, $5 \mathrm{mg} / \mathrm{mL}$ ) assay which measures the activity of mitochondrial succinate dehydrogenase in viable cells. The cells were incubated for another $4 \mathrm{~h}$ and the formazan crystals were solubilized using $10 \%$ SDS/PBS/0.01 N HCl. After $14 \mathrm{~h}$, the absorbance of the formazan solution was measured at 570 $\mathrm{nm}$ and $\lambda 630 \mathrm{~nm}$ using BioTek plate reader (EL x 808, BioTek Instruments, Inc., Winooski, VT, USA). The assay was carried out in triplicate. The $I_{50}$ was calculated in terms of the concentration that caused $50 \%$ inhibition of cell growth [8].

\section{Statistical analysis}

All statistical analyses were performed using GraphPad InStat software, version 3.05 (GraphPad Software, La Jolla, CA). Graphs were plotted using GraphPad Prism software, version 6.00 (GraphPad Software, La Jolla, CA).

\section{RESULTS}

Extensive fractionation of the $n$-hexane extract of Laurencia majuscula, employing different chromatographic techniques, led to isolation of eight metabolites (1-8) namely: 4,10-dibromo-3chloro-7(14)-chamigrene (1); a-isobromocuparene (2); (12E)-cis-maneonene A (3); (12Z)-cismaneonene D (4); (12E)-cis-maneonene $E(5)$; bromlaurenidificin (6); jeddahenyne $A$ (7) and cuparen-3-ol (8). The structures of these compounds were elucidated via interpretation of their spectra, including $1 \mathrm{D}$ and $2 \mathrm{D}$ as well as NMR and MS, and comparison with reported data [9-14].

The cytotoxicity of the non-polar extract and isolated compounds 1-8 (Figure 1) were assessed against three cancer cell lines HCT116, PC-3 and HepG2, with cisplatin as standard cytotoxic drug, using MTT assay. The results are shown in Table 1.

\section{DISCUSSION}

The genus Laurencia (Rhodomelaceae) comprises 146 taxonomical species, and it is recognized as one of the best sources of promising secondary metabolites. The worldwide distribution (tropical, subtropical, and temperate coastal waters) and chemical diversity of these species are due to genetic and environmental factors which have resulted in a limitless array of natural compounds [9]. 
Table 1: Cytotoxic activity of $n$-hexane extract of $L$. majuscula and isolated compounds (1-8) against three cancer cell lines

\begin{tabular}{lccc}
\hline Compound/extract & & IC $_{\mathbf{5 0}}(\mu \mathrm{g} / \mathrm{mL})^{\mathrm{a}}$ & HepG2 \\
\cline { 2 - 4 } & HCT-116 & $\mathbf{P C}-\mathbf{3}$ & $29.00 \pm 0.35$ \\
\hline Extract & $33.00 \pm 0.10^{\mathrm{b}}$ & $55.00 \pm 0.17$ & $52.00 \pm 0.44$ \\
1 & $59.34 \pm 0.32$ & $92.00 \pm 0.40$ & $58.00 \pm 0.50$ \\
2 & $46.70 \pm 0.20$ & $66.00 \pm 0.40$ & $>200$ \\
3 & $>200$ & $>200$ & $>200$ \\
4 & $>200$ & $>200$ & $>200$ \\
5 & $>200$ & $>200$ & $141.00 \pm 1.18$ \\
6 & $150.00 \pm 0.90$ & $187.00 \pm 1.07$ & $>200$ \\
7 & $147.40 \pm 0.80$ & $200.00 \pm 0.75$ & $65.75 \pm 1.40$ \\
8 & $43.15 \pm 0.20$ & $60.00 \pm 0.31$ & $01.65 \pm 0.06$ \\
Cisplatin & $03.78 \pm 0.09$ & $01.50 \pm 0.04$ &
\end{tabular}

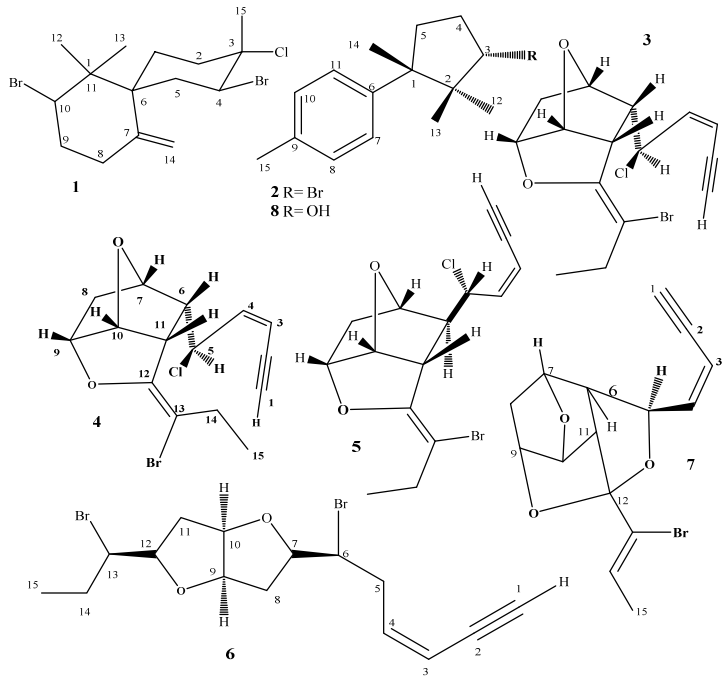

Figure 1: Compounds isolated from L. majuscule (1-8)

The major chemical classes reported from Laurencia are sesquiterpenes, diterpenes, triterpenes, and C-15 acetogenins. In addition to these classes, indoles, aromatic compounds and steroids are present in Laurencia majuscula as miscellaneous metabolites. Sesquiterpenes are the largest group, comprising more than 512 compounds and related metabolites belonging to more than 50 carbon outlines. Diterpenes are recognized as the second most important chemical classes which were identified in Laurencia majuscula. They constitute more than 133 metabolites and are categorized under 25 skeletons.

Cancer is one of the most serious illnesses in humans, and one of the leading causes of death worldwide [15]. Natural compounds with potent biological effects are considered as lead and promising reservoirs from which modern medicine is derived, particularly for treatment of cancer. In vitro cell proliferation assays are most widely used for evaluating preliminary antitumor effects of synthetic and natural compounds. These tests give an indication of cytotoxicity, but in order to determine the mechanism of action, specialized assays are required [16]. On these bases, Laurencia majuscula extract was fractionated to eight compounds which were evaluated for their cytotoxic effects against three cancer cell lines.

The extract showed significant cytotoxic effect against the three cell lines tested: HCT-116 (human colon cancer cells), PC-3 (human prostate cancer cells) and HepG2 (human hepatocellular carcinoma cells). The extract, isolated compounds and cisplatin (positive control) showed significant cytotoxic activities against HCT-116, PC-3 and PC-3. Based on these data, it is obvious that the n-hexane extract was more potent than the isolated compounds. This could be due to some sort of synergistic/agonistic effect of the compounds, or it could be that the bioactive compound in its natural form is more potent than the isolated one.

\section{CONCLUSION}

The $n$-hexane extract of the red alga, Laurencia majuscula, exhibits cytotoxic effect against three cancer cell lines HCT-116, PC-3 and HepG2. Fractionation of the extract led the isolation of eight terpenoid derivatives. The isolated sesquiterpenes are more potent than the isolated acetogenins containing polyketides.

\section{DECLARATIONS}

\section{Acknowledgement}

This project was funded by the Deanship of Scientific Research (DSR) at King Abdulaziz University, Jeddah (grant no. G-482-247-39). The authors, therefore, acknowledge with thank DSR for the technical and financial support. 


\section{Conflict of interest}

No conflict of interest is associated with this work.

\section{Contribution of authors}

We declare that this work was done by the authors named in this article and all liabilities pertaining to claims relating to the content of this article will be borne by the authors.

\section{Open Access}

This is an Open Access article that uses a funding model which does not charge readers or their institutions for access and distributed under the terms of the Creative Commons Attribution License (http://creativecommons.org/licenses/by/ 4.0) and the Budapest Open Access Initiative (http://www.budapestopenaccessinitiative.org/rea d), which permit unrestricted use, distribution, and reproduction in any medium, provided the original work is properly credited.

\section{REFERENCES}

1. Anis M, Ahmed S, Hasan MM. Algae as nutrition, medicine and cosmetic: the forgotten history, present status and future trends. World J Pharm Pharm Sci 2017; 6: 1934-1959

2. Abou-Elnaga ZS, Alarif WM, Al-lihaibi SS. New larvicidal acetogenin from the red alga Laurencia papillosa. CLEAN - Soil, Air, Water 2011; 3: 787-794.

3. Massarani S. Phytochemical and biological properties of sesquiterpene constituents from the marine red seaweed Laurencia: A Review. Nat Prod Chem Res 2014; 2(5): 1-13.

4. Suzuki M, Vairappan CS. Halogenated secondary metabolites from Japanese species of the red algal genus Laurencia (Rhodomelaceae, Ceramiales). Curr Topics Phytochem 2005; 5: 1-38.

5. Chatter R, Othman RB, Rabhi S, Kladi M, Tarhouni S, Vagias C, Roussis V, Guizani-Tabbane L, Kharrat R. In vivo and in vitro anti-inflammatory activity of neorogioltriol, a new diterpene extracted from the red algae Laurencia glandulifera. Marine Drugs 2011; 9: 1293-1306.

6. Juagdan EG, Kalidindi $R$, Scheuer $P$. Two new chamigrenes from Hawaiian red alga, Laurencia cartilaginea. Tetrahedron 1997; 53: 521-528.

7. Feoktistova M, Geserick P, Leverkus, M. Crystal Violet Assay for determining viability of cultured cells. Cold Spring Harbor Protocols 2016; pp 343-346.

8. El-Naggar MH, Mira A, Bar FMA, Shimizu K, Amer MM, Badria FA. Synthesis, docking, cytotoxicity, and LTA $4 \mathrm{H}$ inhibitory activity of new gingerol derivatives as potential colorectal cancer therapy. Bioorg Med Chem 2017; 25(3): 1277-1285.

9. Waraszkiewicz SM, Erickson KL. Halogenated sesquiterpenoids from the hawaiian marine alga Laurencia nidifica. Nidificene and nidifidiene. Tetrahedron Lett 1974; 23: 2003-2006.

10. Suzuki T, Suzuki M, Kurosawa E. $\alpha$-Bromocuparene and a-isobromocuparene, new bromo compounds from Laurencia species J. Tetrahedron Lett 1975; 16: 30573058.

11. Waraszkiewics SM, Sun HH, Erickson KL. C15 halogenated compounds from the Hawaiian marine alga Laurencia nidifica. Maneonenenes and isomaneonenens. J Org Chem 1978; 43: 3194-3204.

12. Ayyad S-EN, Al-Footy KhO, Alarif WM, Sobahi TR, Basaif SA, Makki MS, Asiri AM, Alhalwani AY, Badria FA. Bioactive C15 Acetogenins from Red Alga Laurencia obtusa. Chem Pharm Bull 2011; 59: 1294-1298.

13. Bawakid NO, Alarif WM, Alburae NA, Alorfi HS, Al Footy KO, Al Lihaibi SS, Ghandourah MA. Isolaurenidificin and bromlaurenidificin, two new C15 acetogenins from the red alga Laurencia obtusa. Molecules 2017; 22: 807815.

14. Bawakid NO, Alarif WM, Ismail Al, El Hefnawy ME, Al Footy KO, Al Lihaibi SS. Bio active maneonenes and isomaneonene from the red alga Laurencia obtusa. Phytochem 2017; 143: 180185.

15. Kinghorn $A D$, Falk $H$, Gibbons $S$, Kobayashi J. (eds.), Progress in the Chemistry of Organic Natural Products, Vol. 102, Springer International Publishing Switzerland 2016.

16. Blunt JW, Copp BR, Keyzers RA, Munro MHG, Prinsep MR. Marine natural products. Nat Prod Rep 2015; 32 : 116. 